\title{
Organochlorines and trace metals in green-lipped mussels Perna viridis from Hong Kong waters: a test of indicator ability
}

\author{
D. J. H. Phillips \\ Environmental Prolection Agency, Empire Centre, Tsim Sha Tsui, Kowloon, Hong Kong
}

\begin{abstract}
Whilst the use of biological indicators to quantify aquatic pollution by trace elements and organochlorines is well-established in temperate waters, this technique has been relatively little used in tropical areas. This is partly because a suitable species has yet to be identified. In South-East Asia, the green-lipped mussel Perna viridis (Linnaeus) has been proposed as a candidate for regional bioindicator studies. The capacity of $P$. viridis to act as an efficient and accurate bio-indicator for trace metals and organochlorines has been tested in Hong Kong coastal waters, using samples from 15 locations. It is concluded that $P$. viridis is an excellent bio-indicator species for studies of copper and lead. Its use to monitor cadmium, mercury and zinc requires further study, however; in particular, the mussel may partially metabolically regulate zinc concentrations in its tissues. $P$. viridis appears to be a capable indicator species for organochlorines; the data reported here reveal a generalized contamination of Victoria Harbour by DDT and its metabolites, and localized pollution by PCBs.
\end{abstract}

\section{INTRODUCTION}

The techniques of using biological indicators or sentinel organisms to monitor aquatic pollution by conservative contaminants are now well proven (Bryan, 1976, 1980; Phillips, 1980a). National and international programmes employing bio-indicators have been established in the last decade, and have contributed much to our understanding of marine and estuarine pollution in particular

The most commonly used bio-indicator species are bivalve molluscs, which conform particularly well to the attributes required of such monitoring organisms. In temperate regions, species of the genera Mytilus and Crassostrea have been widely used with considerable success; their cosmopolitan distribution has enabled studies to be carried out over large geographical areas (e.g. Butler, 1973; De Wolf, 1975; Bernhard, 1978; Goldberg et al., 1978, 1983; Farrington et al., 1983).

However, bio-indicator studies in tropical and subtropical areas of the world have lagged behind those in temperate regions. One of the reasons for this has been the unavailability of a bio-indicator species which has a sufficiently widespread geographical distribution and has also been unequivocally demonstrated to pos- sess the required indicator ability. It has been suggested that in South-East Asia, the best candidate for bio-indicator surveys is the green-lipped mussel Perna viridis (Phillips, 1980b; IOC, 1981). The accumulation of contaminants by this species (also known as Mytilus smaragdinus and various other combinations of nomenclature; see Siddall, 1980) has been studied by several authors (e.g. D'Silva and Kureishy, 1978; Sivalingam and Bhaskaran, 1980; Menasveta and Cheevaparanapiwat, 1981; Hungspreugs et al,, 1984; Hungspreugs and Yuangthong, 1984; Phillips and Muttarasin, in press). Data are also available for trace element accumulation in the closely related species Perna canaliculus from New Zealand (Hoggins and Brooks, 1973; Nielsen, 1974; Nielsen and Nathan, 1975). However, the studies to date on $P$. viridis cannot be said to have unequivocally established its capacity to act as a bio-indicator.

Monitoring studies in tropical regions are urgently required at present. Many tropical nations are undergoing rapid industrialization, and contamination of their coastal environments by conservative pollutants is increasing. In addition, there is concern presently that the use of organochlorine compounds is increasing in tropical areas, thus fulfilling the predictions in the 'southward tilt' theory (Goldberg, 1975, 1983). 
The present paper reports the results of a survey of trace elements and organochlorines in Perna viridis taken from 15 locations in the coastal waters of Hong Kong. By relating these data to the results of previous studies using rock oysters, mussels and sediments (Phillips, 1979; Phillips and Yim, 1981), the ability of $P$. viridis to act as an efficient and accurate bio-indicator species has been assessed, and the degree of contamination of local waters by organochlorines has been determined.

\section{MATERLALS AND METHODS}

Samples of mussels Perna viridis (Linnaeus) were collected from wild populations at low tides or by Scuba diving at 15 locations in Hong Kong coastal waters (Fig. 1) between 8 July and 8 August 1983. Care was taken to sample individuals of similar size (shell lengths were $57 \pm 5.4 \mathrm{~mm}$ for metal samples and $73 \pm 12.8 \mathrm{~mm}$ for organochlorine samples) at all locations as far as this was possible, as size or tissue weight is known to sometimes affect trace element levels in mussels (e.g. Boyden, 1977; Phillips, 1980a). In addition, all samples were taken at similar depths with respect to tide marks (within $0.1 \mathrm{~m}$ of $+0.4 \mathrm{~m} \mathrm{PD}$ ), as the vertical position on the shore line may also influence contaminant concentrations in bio-indicators, particularly in estuarine areas. Surface sediment and epibiota were removed from the shells and individuals were placed in aluminium foil (organochlorine analysis samples) or clean polythene bags (trace element samples) and kept cool during transport to the laboratory. The samples were then frozen without prior depuration. Most authors advise against depurating samples for organochlorine analysis, as contaminants of short biological half-lives may be lost in the depuration period (NAS, 1980). For trace element studies, depuration is commonly preferred, as the gut contents may contribute quite large amounts of metals, particularly in smaller animals (Flegal and Martin, 1977). However, depuration affects element levels in a quite minor fashion in mussels, at least for metals other than iron and aluminium which are heavily associated with inorganic particulate material (NAS, 1980; Latouche and Mix, 1982).

When required for analysis, samples were thawed and shucked using stainless steel instruments. The byssus was discarded. All instruments used for preparing the samples for organochlorine analysis were thoroughly rinsed in hexane and the usual precautions (e.g. Bernhard, 1976) were taken to avoid contamina-

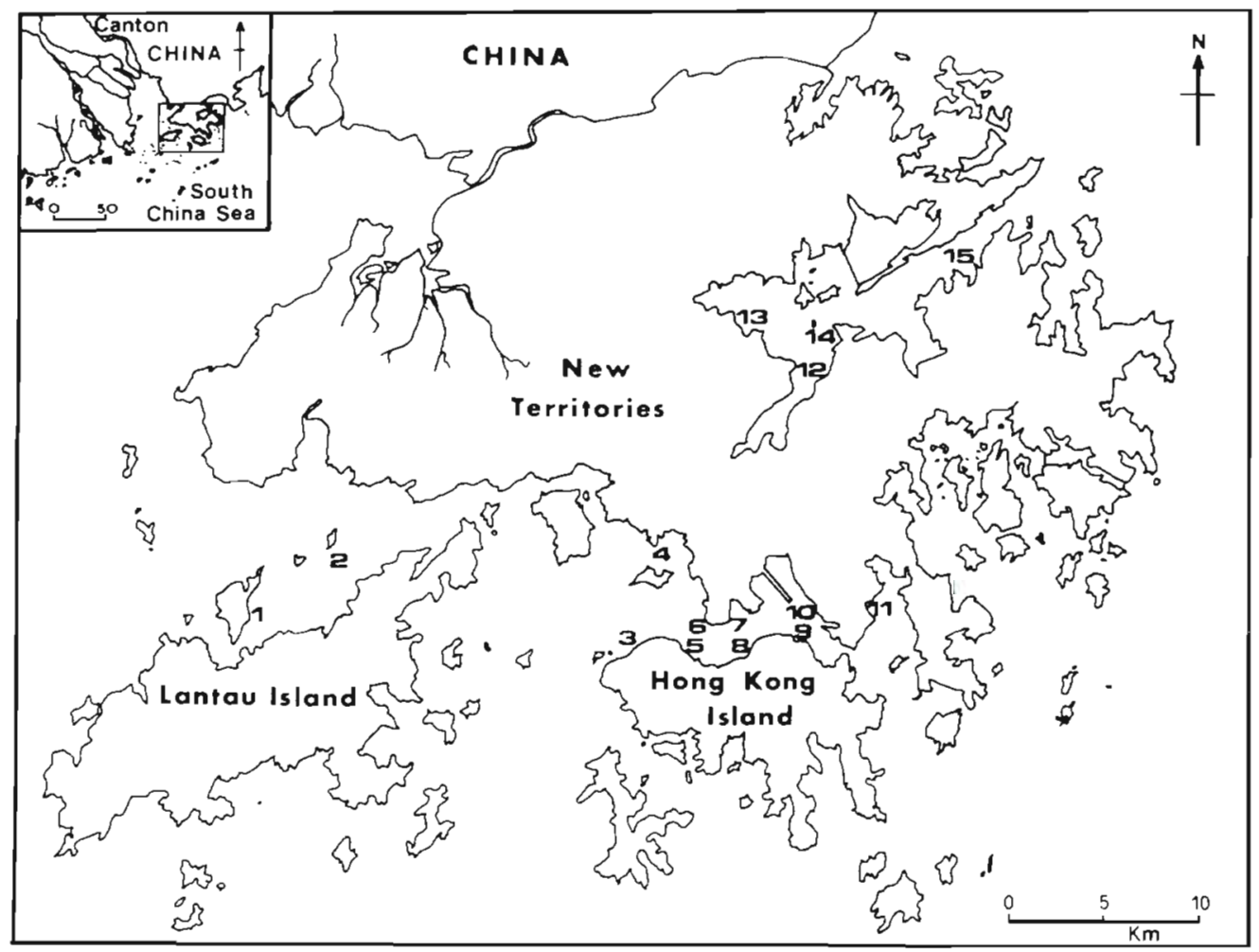

Fig. 1. Perna viridis. Location of 15 sampling sites for mussels in Hong Kong coastal waters. Sites 1 and 2 are west of Victoria Harbour; Sites 3 to 10 are within Victoria Harbour. Site 11 is in Junk Bay, and Sites 12 to 15 are in Tolo Harbour and Channel. Insert shows Hong Kong in relation to Canton and southern China 
tion in any part of the procedures. The mussels were not sexed, as sex has been found to be unimportant in influencing contaminant concentrations in Perna viridis (Phillips, unpubl., compare to Watling and Watling, 1976; Young et al., 1976; Orren et al., 1980; Klumpp and Burdon-Jones, 1982; Lobel and Wright, 1982; Lobel et al., 1982). For each location, 25 individuals were taken to characterize trace element concentrations, and these were homogenized in a commercial blender (shown in unpublished studies to be non-contaminating) and analysed as a pooled sample. A further 25 individuals were taken for organochlorine analysis; these were also analysed as a bulk sample for each location. The available literature (Gordon et al., 1980; Boyden and Phillips, 1981) suggests that this number is sufficient to characterize pollutant levels in bivalve populations.

For the analysis of trace elements other than mercury, a $5 \mathrm{~g}$ aliquot of each sample homogenate was digested at $100^{\circ} \mathrm{C}$ in a water bath with $20 \mathrm{ml}$ concentrated nitric acid, and made up to $100 \mathrm{ml}$ thereafter Cadmium, copper and zinc were determined by atomic absorption spectrophotometry using a Hitachi 180-80 Zeeman instrument in flame mode; lead analysis was performed on a Perkin Elmer PE 4000 with graphite furnace. Mercury was determined using a separate $1 \mathrm{~g}$ aliquot of each homogenate, digested with nitric and sulphuric acids for $2 \mathrm{~h}$. A solution of $6 \% \mathrm{KMnO}_{4}$ was added slowly and the digest left to stand overnight. Thereafter, $30 \% \mathrm{H}_{2} \mathrm{O}_{2}$ was added to discolour the solution and mercury was determined on a Perkin Elmer PE 50A analyser, using stannous chloride as the reductant. Quality control was ensured by the use of blanks, by standard addition in some cases, and by the analysis of a range of intercomparison and reference materials. For example, during this particular study, the albacore tuna reference material (RM 50) from the National Bureau of Standards, USA, was employed to provide quality control for the analysis of lead, mercury and zinc. Laboratory data averaged $0.28 \mu \mathrm{g} \mathrm{g}^{-1}$ dry wt for $\mathrm{Pb}, 0.97 \mu \mathrm{g} \mathrm{g}^{-1}$ dry wt for $\mathrm{Hg}$ and $14.7 \mu \mathrm{g} \mathrm{g}^{-1}$ dry wt for $\mathrm{Zn}$. These may be compared to NBS reported values of $0.46 \mu \mathrm{g} \mathrm{g}^{-1}$ for $\mathrm{Pb}$ ('average value'), $0.95 \pm$ $0.01 \mathrm{~g} \mathrm{~g}^{-1}$ for $\mathrm{Hg}$ ('most probable value') and $13.6 \pm$ $1.0 \mu \mathrm{g} \mathrm{g}^{-1}$ for $\mathrm{Zn}$ ('estimated probable value'). The dry weights of all samples, both for trace metal and organochlorine analysis, were determined on separate aliquots of the relevant homogenates by drying at $100^{\circ} \mathrm{C}$ to constant weight. All analytical results reported are based upon these dry weights.

For organochlorines, $40 \mathrm{~g}$ of each homogenate was digested at room temperature in concentrated $\mathrm{HCl}$, and subsequently extracted 4 times with $25 \%$ methylene chloride in n-hexane. The extract was neutralized, dried over anhydrous $\mathrm{Na}_{2} \mathrm{SO}_{4}$, and made up to $200 \mathrm{ml}$ with n-hexane. Cleanup involved treating this extract with concentrated $\mathrm{H}_{2} \mathrm{SO}_{4}$, neutralization, and evaporation to remove the solvent. Iso-octane was added in the last stages of evaporation to remove all traces of methylene chloride. The residue was transferred to a $1 \mathrm{~cm}$ diameter column, slurry-packed with Kieselgel 60 (activated at $130^{\circ} \mathrm{C}$ overnight and deactivated with $6 \%$ water) and topped with $2 \mathrm{~g}$ anhydrous $\mathrm{Na}_{2} \mathrm{SO}_{4}$. Elution with $50 \mathrm{ml}$-hexane gave a fraction containing HCB, DDE and PCBs; HCH isomers, DDD and DDT were eluted by use of $40 \mathrm{ml} 25 \%$ diethyl ether in $\mathrm{n}$ hexane. All compounds were determined on a Tracor 565 gas chromatograph with a $1.8 \mathrm{~m} \times 4 \mathrm{~mm}$ column at $190^{\circ} \mathrm{C}$ or $200^{\circ} \mathrm{C}$ (PCBs). Quantification was on the basis of peak heights; in the case of PCBs, the 3 major peaks in samples were compared to the commercial standard most resembling the profiles (Aroclor 1242 in all cases other than the sample from Location 8 , for which Aroclor 1232 was used). Lipid contents were determined on a separate extract by evaporation under a stream of nitrogen and heating at $100^{\circ} \mathrm{C}$ for five minutes to determine weight loss. Quality control of analysis was assured by the concurrent analysis of blanks and spiked samples. Inter-laboratory comparisons are also used to provide quality control when samples are available; the laboratory performed well in the Intergovernmental Oceanographic Commissionsponsored exercise for organochlorines in 1982/1983.

\section{RESULTS}

Concentrations of the 5 trace elements studied in the samples of Perna viridis are shown in Table 1, which also includes collection dates and data for shell lengths and tissue weights of the samples analysed. Concentrations of cadmium, copper and lead varied widely between mussel samples; the ratios of highest to lowest values recorded were 21 -fold for $\mathrm{Cd}, 33$-fold for $\mathrm{Cu}$ and 43-fold for $\mathrm{Pb}$. Concentrations of mercury were below the detection limit of $0.11 \mu \mathrm{g} \mathrm{g}^{-1}$ dry weight for all samples except 2 (from Kwun Tong and North Point in eastern Victoria Harbour; Fig. 1), both of which were barely above detection limits. Zinc concentrations varied by slightly greater than a 2 -fold range, from 77 to $164 \mu^{-1} \mathrm{~g}^{-1}$ dry weight.

Data concerning organochlorines in mussel samples from the same 15 locations are presented in Table 2. Shell lengths, tissue weights and lipid contents of these samples are also shown. The lipid contents varied from 0.68 to $1.9 \%$ (almost 3 -fold). This is significant in that it suggests variability in sexual condition of the samples between locations; the concentrations of organochlorines found in the samples may be influenced to some extent by lipid variations (Phillips, 
Table 1. Perna viridis. Sampling dates, shell lengths, soft tissue wet weights and trace element concentrations in mussels from 15 locations in Hong Kong coastal waters. Data for metals represent concentrations (as $\mu \mathrm{g} \mathrm{g}^{-1} \mathrm{dry}$ wt) present in pooled homogenates of 25 individuals in each location. See Fig. 1 for collection sites

\begin{tabular}{|c|c|c|c|c|c|c|c|c|c|}
\hline Sample & Location & $\begin{array}{l}\text { Sampling } \\
\text { date }\end{array}$ & $\begin{array}{c}\text { Shell } \\
\text { length }(\mathrm{mm})\end{array}$ & $\begin{array}{l}\text { Wet tissue } \\
\text { weight }(g)\end{array}$ & $\begin{array}{l}\text { Cad- } \\
\text { mium }\end{array}$ & Copper & Lead & Mercury & Zine \\
\hline 1 & Chek Lap Kok & $8 \mathrm{Jul} 1983$ & $54 \pm 4.8$ & $4.3 \pm 1.1$ & 1.23 & 10.5 & 5.1 & $<0.11$ & 128 \\
\hline 2 & Reef Island & 8 Jul 1983 & $57 \pm 3.9$ & $4.0 \pm 0.7$ & 1.44 & 10.2 & 3.1 & $<0.11$ & 126 \\
\hline 3 & Kennedy Town & 8 Aug 1983 & $56 \pm 6.4$ & $5.9 \pm 1.4$ & 0.29 & 11.5 & 12.6 & $<0.11$ & 115 \\
\hline 4 & Mei Foo & $25 \mathrm{Jul} 1983$ & $57 \pm 6.0$ & $5.6 \pm 0.8$ & 0.31 & 30.3 & 18.0 & $<0.11$ & 118 \\
\hline 5 & Queens Pier & 26 Jul 1983 & $57 \pm 4.5$ & $4.8 \pm 0.9$ & 0.19 & 15.7 & 9.4 & $<0.11$ & 126 \\
\hline 6 & Kowloon Pier & $25 \mathrm{Jul} 1983$ & $63 \pm 4.7$ & $6.0 \pm 1.1$ & 0.21 & 22.8 & 8.3 & $<0.11$ & 118 \\
\hline 7 & Hung Hom & 25 Jul 1983 & $64 \pm 10.2$ & $7.7 \pm 2.9$ & 0.18 & 31.6 & 18.2 & $<0.11$ & 164 \\
\hline 8 & Causeway Bay & $26 \mathrm{Jul} 1983$ & $52 \pm 6.8$ & $3.6 \pm 1.1$ & 0.07 & 15.6 & 7.8 & $<0.11$ & 137 \\
\hline 9 & North Point & 8 Aug 1983 & $57 \pm 5.9$ & $4.9 \pm 1.2$ & 0.18 & 38.1 & 15.5 & 0.12 & 149 \\
\hline 10 & Kwun Tong & 8 Aug 1983 & $67 \pm 6.2$ & $5.9 \pm 1.6$ & 0.29 & 278.5 & 19.3 & 0.14 & 129 \\
\hline 11 & Rennies Mill & 8 Aug 1983 & $63 \pm 11.0$ & $8.0 \pm 3.1$ & 1.43 & 16.0 & 60.5 & $<0.11$ & 143 \\
\hline 12 & Sha Tin & $10 \mathrm{Jul} 1983$ & $49 \pm 3.5$ & $2.6 \pm 0.5$ & 0.55 & 29.4 & 7.5 & $<0.11$ & 89 \\
\hline 13 & Tai Po Kau & $10 \mathrm{Jul} 1983$ & $51 \pm 2.4$ & $3.3 \pm 0.4$ & 0.38 & 20.1 & 2.7 & $<0.11$ & 88 \\
\hline 14 & Wu Kwai Sha & 10 Jul 1983 & $52 \pm 2.8$ & $3.5 \pm 0.7$ & 0.30 & 20.8 & 4.3 & $<0.11$ & 77 \\
\hline 15 & Lai Chi Chong & $10 \mathrm{Jul} 1983$ & $52 \pm 3.5$ & $3.6 \pm 0.5$ & 0.59 & 8.5 & 1.4 & $<0.11$ & 79 \\
\hline
\end{tabular}

1980a). Hexachlorobenzene ( $\mathrm{HCB}$ ) was not found in any sample. Isomers of hexachlorocylohexane $(\mathrm{HCH})$ were found at low concentrations in 7 of the 15 mussel samples, all but one of these being in the Victoria Harbour area. PCBs were present at levels above the detection limits in 4 samples. DDT and its metabolites were found in all samples. The highest levels of DDT were again found in mussels from Victoria Harbour, although mussels from inner Tolo Harbour also contained significant amounts of these compounds. Where all residue levels for the DDT group of compounds were above detection limits their sum (' $\Sigma D D T$ ') has been calculated and the ratio of the parent compound to this sum of all DDT-type residues has also been computed; these data are also shown in Table 2

\section{DISCUSSION AND CONCLUSIONS}

The waters of Hong Kong provide an ideal environment in which to test the performance of potential bioindicator species in monitoring certain conservative pollutants. This is because of the considerable asymmetry in contamination of the coastal area of Hong Kong by sewage and industrial wastes. More than $65 \%$ of the overall population (and a similar proportion of

Table 2. Perna viridis. Shell lengths, soft tissue wet weights, lipid contents, and concentrations (ng $\mathrm{g}^{-1}$ dry wt) of hexachlorobenzene $(\mathrm{HCB})$, hexachlorocyclohexane $(\mathrm{HCH})$, polychlorinated biphenyls (PCBs) and DDT, DDE and DDD in mussels from 15 locations in Hong Kong coastal waters. All concentration data refer to homogenates of 25 individuals. See Fig. 1 for collection locations, and Table 1 for dates of sampling. NC: not calculated

\begin{tabular}{|c|c|c|c|c|c|c|c|c|c|c|c|c|}
\hline Sample & Location & $\begin{array}{l}\text { Shell } \\
\text { length } \\
\text { (mm) }\end{array}$ & $\begin{array}{c}\text { Wet tissue } \\
\text { weight } \\
\text { (g) }\end{array}$ & $\begin{array}{c}\text { Lipid } \\
\text { content } \\
(\%)\end{array}$ & $\mathrm{HCB}$ & $\mathrm{HCH}$ & $P C B s$ & DDT & DDE & DDD & $\Sigma D D T$ & $\frac{\text { DDT }}{\Sigma D D T}$ \\
\hline 1 & Chek Lap Kok & $71 \pm 4.5$ & $7.9 \pm 1.0$ & 0.68 & $<30$ & $<30$ & $<60$ & $<30$ & $<30$ & 26 & $\mathrm{NC}$ & $\mathrm{NC}$ \\
\hline 2 & Reef Island & $76 \pm 3.8$ & $7.0 \pm 1.2$ & 0.72 & $<30$ & 211 & $<60$ & $<30$ & $<30$ & 30 & $\mathrm{NC}$ & $\mathrm{NC}$ \\
\hline 3 & Kennedy Town & $77 \pm 12.5$ & $11.8 \pm 3.7$ & 1.90 & $<30$ & $<30$ & $<60$ & 745 & 106 & 213 & 1064 & 70 \\
\hline 4 & Mei Foo & $79 \pm 7.8$ & $9.9 \pm 1.8$ & 1.30 & $<30$ & 92 & $<60$ & $<30$ & 86 & 221 & NC & $\mathrm{NC}$ \\
\hline 5 & Queens Pier & $92 \pm 4.8$ & $13.6 \pm 2.9$ & 0.97 & $<30$ & 61 & $<60$ & 306 & 61 & 123 & 490 & 62 \\
\hline 6 & Kowloon Pier & $75 \pm 5.4$ & $7.7 \pm 1.1$ & 0.97 & $<30$ & $<30$ & $<60$ & 439 & $<30$ & 568 & $\mathrm{NC}$ & $\mathrm{NC}$ \\
\hline 7 & Hung Hom & $83 \pm 13.3$ & $12.5 \pm 3.6$ & 1.20 & $<30$ & 52 & $<60$ & $<30$ & 75 & 185 & NC & $\mathrm{NC}$ \\
\hline 8 & Causeway Bay & $56 \pm 9.9$ & $4.5 \pm 1.8$ & 1.30 & $<30$ & 88 & 1696 & 760 & 140 & 415 & 1315 & 58 \\
\hline 9 & North Point & $85 \pm 7.5$ & $10.5 \pm 1.9$ & 1.20 & $<30$ & 49 & $<60$ & 219 & 67 & 213 & 499 & 52 \\
\hline 10 & Kwun Tong & $83 \pm 5.5$ & $8.7 \pm 1.2$ & 0.96 & $<30$ & 44 & $<60$ & 56 & 69 & 131 & 256 & 22 \\
\hline 11 & Rennies Mill & $86 \pm 6.6$ & $13.9 \pm 2.6$ & 1.70 & $<30$ & $<30$ & 1904 & 466 & 667 & 910 & 2043 & 23 \\
\hline 12 & Sha Tin & $61 \pm 4.8$ & $5.0 \pm 1.2$ & 1.10 & $<30$ & $<30$ & 131 & 231 & 237 & 400 & 868 & 27 \\
\hline 13 & Tai Po Kau & $62 \pm 3.2$ & $5.4 \pm 0.9$ & 0.75 & $<30$ & $<30$ & $<60$ & 54 & 60 & 223 & 337 & 16 \\
\hline 14 & Wu Kwai Sha & $60 \pm 5.4$ & $5.4 \pm 1.1$ & 0.86 & $<30$ & $<30$ & $<60$ & 364 & 121 & 636 & 1121 & 32 \\
\hline 15 & Lai Chi Chong & $48 \pm 3.5$ & $2.9 \pm 0.5$ & 1.10 & $<30$ & $<30$ & 216 & 43 & $<30$ & 56 & $N C$ & $\mathrm{NC}$ \\
\hline
\end{tabular}


the industry) exists in or around the area of Victoria Harbour, between Hong Kong Island and the Kowloon Peninsula. Most wastes are discharged directly into the Harbour with little or no pre-treatment. Previous studies using oysters, mussels and sediments (Phillips, 1979; Phillips and Yim, 1981) have clearly shown that the Victoria Harbour area is more highly contaminated by copper and zinc than are the surrounding waters The same is true of lead and nickel (Phillips, unpubl.), although cadmium contamination does not follow this pattern of generally greater abundance in the Harbour, but is locally elevated at only certain sites (Phillips, 1979). No data are available on the distribution of mercury throughout local waters, but elevated levels of this element might be expected in Victoria Harbour due to industrial discharges.

Data from the present study may thus be compared to the results from previous investigations and to the known distribution of industry and the human population to reveal the capacity of the green-lipped mussel Perna viridis to act as a bio-indicator species for trace elements. Consideration of Table 1 reveals differences between the elements in terms of their variability in concentration in $P$. viridis from overtly clean locations (e.g. Location 15 in the eastern Tolo area or Locations 1 and 2 to the west of Victoria Harbour; Fig. 1) and from known areas of contamination in Victoria Harbour. Thus, concentrations of copper and lead varied over a wide range, with maxima in areas of known pollution (especially industrial pollution). By contrast, concentrations of zinc varied over only a 2 -fold range.

Comparison of these data to previous results for trace elements in oysters, mussels and sediments from similar locations (Phillips, 1979; Phillips and Yim, 1981; also unpublished data) confirms the capacity of Perna viridis to monitor copper and lead. Thus, the eastern extremity of Victoria Harbour was previously shown to be the most highly contaminated area with respect to copper $; P$. viridis also reflects this profile. The major sources of copper include industries in Kwun Tong and to the east of Hong Kong Island. A similar pattern is seen for lead in $P$, viridis, although in this case the maximum value is located in Junk Bay. The major sources of lead in local waters are also believed to be industrial. It is notable that the north-eastern locations (numbered 12 to 15 in Fig. 1) and the sites to the west of Victoria Harbour (1 and 2 in Fig. 1) are those of lowest lead concentrations in $P$. viridis; this clearly shows the influence of the anthropogenic discharges in Victoria Harbour. A similar, but less marked increase in lead concentrations is seen in mussels from the Tolo estuary (Locations 12 to 15), which are exposed to sewage and industrial effluents from satellite towns at Locations 12 and 13 .

The capacity of Perna viridis to act as an efficient bio-indicator for cadmium and mercury is more difficult to ascertain from these data, as the asymmetry in environmental abundance of these elements in Hong Kong is less marked or not proven to date. No major sources of cadmium exist in Hong Kong coastal waters (Phillips, 1979), although local small-scale contamination was noted in previous studies of oysters. Whilst profiles of cadmium contamination in $P$. viridis in the present work agree generally with previous data, it is considered that a more rigorous test of the indicator capacity of $P$. viridis is required, preferably close to known major sources of cadmium. Similarly, the lack of major mercury contamination in local seafoods (Phillips et al., 1982) points to a dearth of mercury hotspots in Hong Kong. The minor elevation of mercury concentrations in mussels from western Victoria Harbour (Locations 9 and 10) lends some confidence to the assumption that $P$. viridis acts as an efficient bioindicator for this element, but further studies in more polluted locations are needed.

Zinc concentrations in Perna viridis analysed in the present study varied from 77 to $164 \mu \mathrm{g} \mathrm{g}^{-1}$ dry weight. This range is surprisingly narrow, as Victoria Harbour is known to be heavily contaminated by zinc compared to the surrounding waters. Previous studies on oysters noted a 3 -fold to 7 -fold difference in concentrations of zinc between locations in Victoria Harbour and those elsewhere (Phillips, 1979; Phillips and Yim, 1981), and studies of sediments have reached similar conclusions. Table 3 presents results for zinc and other metals in $P$. viridis from the published literature. It is notable that whilst the concentrations of cadmium, copper and lead reported for $P$. viridis vary widely with location (as noted also in the present work), the zinc concentrations are all close to or within the range found for Hong Kong samples. It is possible that zinc is partially metabolically regulated in $P$. viridis, as has been suggested for the same element in the mussels Septifer virgatus ${ }^{*}$ and Trichomya hirsuta (Phillips and Yim, 1981; Klumpp and Burdon-Jones, 1982). A relatively slow uptake of zinc from solution by $P$. viridis was reported by D'Silva and Kureishy (1978), which might lend further support to this hypothesis. Further studies are required to demonstrate unequivocally the capacity of $P$. viridis to act as a bio-indicator for zinc in aquatic environments.

The data reported here for organochlorines in mussels are the first of their kind for Hong Kong; previous studies of organochlorines have been limited to analysis of a few estuarine sediment samples and of retailed

\footnotetext{
- Named Septifer bilocularis in the original paper (Phillips and Yim, 1981); more recently shown to be $S$. virgatus from studies of type specimens at the British Museum (B. S. Morton, pers. comm.)
} 
Table 3. Perna viridis. Reported concentrations of trace elements ( $\mu \mathrm{g} \mathrm{g}^{-1}$ dry wt) in green-lipped mussels from various locations

\begin{tabular}{|c|c|c|c|c|c|c|}
\hline Location & Cadmium & Copper & Lead & Mercury & Zine & Source \\
\hline Rayong, Thailand" & 2.5 & 48.6 & 0.7 & 0.13 & 94 & Huschenbeth and Harms (1975) \\
\hline Bang Pakong Estuary, Thailand & 3.5 & 8.7 & 241 & 0.09 & 661 & \\
\hline Chao Phraya Estuary, Thailand & 3.4 & 8.7 & 259 & 0.21 & 54 & \\
\hline Ta Chin Estuary, Thailand & 5.0 & 9.0 & 256 & 0.09 & 72 & Menasveta and \\
\hline Mae Klong Estuary, Thailand & 5.2 & 6.2 & 103 & 0.07 & 72 & Cheevaparanapiwat (1981) \\
\hline Hua Tin, Thailand & 2.7 & 7.2 & 13 & 0.04 & $48)$ & \\
\hline Penang, Malaysia & - & 8.0 & 7.0 & - & 76 & Sivalingam and Bhaskaran (1980) \\
\hline Market sample, Hong Kong " & 0.7 & 17.3 & 4.7 & 0.13 & 79 & Phillips et al. (1982) \\
\hline Bang Pakong Estuary, Thailand & 0.7 & 4.9 & 1.2 & - & $136\}$ & Hungspreugs and \\
\hline Ang Sila, Thailand & 0.5 & 6.6 & 1.5 & - & $154\}$ & Yuangthong (1984) \\
\hline Ang Hin, Thailand & 0.4 & 8.5 & 0.7 & - & - & Hungspreugs et al. (1984) \\
\hline Bang Pakong Estuary, Thailand & 1.1 & 10.5 & 0.6 & $<0.12$ & 68 & Phillips and Muttarasin (in press) \\
\hline
\end{tabular}

foodstuffs to protect public health. Information on organochlorine usage in Hong Kong is patchy and incomplete. DDT is known to have been used quite extensively as a pesticide in the past, but this practice is now much diminished. Its use in industry persists, however, for purposes such as mothproofing of fabrics and insecticide formulations. DDE and DDD are not known to be used locally but will of course exist in the environment as metabolic products of DDT, where the latter is present. $\mathrm{HCH}$ has been employed as a pesticide and may also be used by industry in small amounts. HCB is not popular locally for either pesticide formulations or in industry PCB usage in Hong Kong is a subject of some concern at present. Many of the local transformers are PCB-filled; in some instances these are now being replaced or retro-filled with silicone fluids, and the waste PCBs are being shipped to the United Kingdom for disposal. It is possible that illegal dumping has occurred in the past. Certain other industries may also use PCBs and it is notable that the electronics industry in Hong Kong is expanding rapidly at present.

The monitoring data reported here (Table 2) show that DDT and its metabolic products are the most abundant organochlorine pesticides in Hong Kong waters. All samples were below detection limits (30 ng $\mathrm{g}^{-1}$ dry wtj for hexachlorobenzene, and $\mathrm{HCH}$ was found in small amounts in only a few samples. The samples containing $\mathrm{HCH}$ were mostly from Victoria Harbour, suggesting industrial origin (as no agricultural land drains directly to the Harbour). The isolated high value for $\mathrm{HCH}$ at Location 2 is probably related to the use of lindane on agricultural crops on north Lantau Island.

The DDT profiles are of particular interest. Very little DDT was found in mussels from the waters to the west of Hong Kong (Locations 1 and 2). However, the Tolo Harbour and Channel catchment (Locations 12 to
15) was notably contaminated, and this is undoubtedly due to run-off from surrounding agricultural areas. It is possible that current DDT applications in the area are minor, as the majority of the residues found were DDD (and to a smaller extent, DDE). The heavy summer rainfall in Hong Kong gives rise to quite severe soil erosion and it is most likely that these residues have persisted in soils in the catchment from previous years, with perhaps minor additions from pesticide applications still occurring in some areas. The Victoria Harbour area is quite highly contaminated by DDT and its metabolites, and in mussels from locations on the north shore of Hong Kong Island, DDT predominated over DDE and DDD. By contrast, mussels from the Kowloon Peninsula and Junk Bay contained more DDD than either DDT or DDE. The precise reasons for this are uncertain, although it is possible that the DDT: DDE: DDD ratios vary according to whether the industrial discharges of DDT are made directly to the Harbour or via the sewage system. Introduction via the latter route would be likely to enhance the rate of microbial breakdown of the parent compound.

Finally, the concentrations of PCBs found in the samples must be considered. Only 4 samples contained PCBs above the detection limit of $60 \mathrm{ng} \mathrm{g}^{-1}$ dry weight. One of these, taken at Location 15, is from a rural area; in this case, illegal dumping of wastes containing PCBs may be suspected. A coastal ground which was used to dump spoil and certain other wastes existed nearby until recently; sediment sampling across this ground may be considered for future studies. The other positive sample for PCBs in the Tolo area was from Sha Tin, which is a rapidly developing satellite town; the source here is undoubtedly industrial. Mussels from Location 8 in Victoria Harbour exhibited quite high levels of PCBs, but the absence of detectable PCB residues from surrounding locations shows that this is a localized source. The sample was taken close to a 
typhoon shelter which contains large numbers of yachts and also accepts some industrial effluents. It is possible that paints used on the vessels are a source of PCBs in this location (see Jensen et al., 1972). The most contaminated sample, however, was taken at Location 11 in Junk Bay. Its content of $1904 \mathrm{ng} \mathrm{PCB} \mathrm{g}^{-1}$ dry weight is unusually high, and is comparable to levels found in heavily contaminated areas of the USA such as San Pedro and San Diego Harbours (Goldberg et al., 1978; Farrington et al., 1983) or even the Palos Verdes Peninsula (Young et al., 1976). Various possible sources exist, including local industry to the west and north of Junk Bay and a controlled tip to the north-east of the Bay. Further studies using transplanted mussels from Location 2 are in progress to characterize fully the pattern of contamination in this area.

In summary, the present studies have shown that the green-lipped mussel Perna viridis may be successfully used as a bio-indicator to monitor copper and lead in coastal waters. Its capacity to reflect efficiently and accurately ambient concentrations of cadmium, mercury and zinc remains to be unequivocally established, however. Zinc may be partially metabolically regulated and further studies are needed. Where organochlorines are concerned, $P$. viridis is similar in lipid content to most other bivalves and appears to be a capable bio-indicator for both the organochlorine pesticides and PCBs.

Acknowledgements. I thank Dr. S. T Chan and his staff for analytical support, and Dr. Ellen Chan and Miss S.-H. Tam for technical assistance. Miss Lisa Chan typed the manuscript. Dr. S. B. Reed gave permission for the data to be published.

\section{LITERATURE CITED}

Bernhard, M. (1976). Manual of methods in aquatic environment research. Part 3 . Sampling and analyses of biological material. FAO Fish. Tech. Pap 158: 1-124

Bernhard, M. (1978). Heavy metals and chlorinated hydrocarbons in the Mediterranean. Ocean Mgmt 3: 253-313

Boyden, C. R. (1977). Effect of size upon metal content of shellfish. J. mar. biol. Ass. U. K. 57: 675-714

Boyden, C. R., Phillips, D. J. H. (1981). Seasonal variation and inherent variability of trace elements in oysters and their implications for indicator studies. Mar. Ecol. Prog. Ser. 5: $29-40$

Bryan, G. W. (1976). Heavy metal contamination in the sea. In: Johnston, R. (ed.) Marine pollution. Academic Press, London and New York, p. 185-302

Bryan, G. W. (1980). Recent trends in research on heavy-metal contamination in the sea. Helgoländer Meeresunters. 33: 6-25

Butler, P. A. (1973). Organochlorine residues in estuarine molluscs, 1965-1972 - national pesticides monitoring program. Pestic. Monit. J. 6: 238-262

De Wolf, P. (1975). Mercury content of mussels from West European coasts. Mar. Pollut. Bull. 6 (4): 61-63
D'Silva, C., Kureishy, T. W. (1978). Experimental studies on the accumulation of copper and zinc in the green mussel. Mar. Pollut. Bull. 9 (7): 187-190

Farrington, J. W., Goldberg. E. D., Risebrough, R. W., Martin, J. H., Bowen, V. T. (1983). U. S. 'Mussel watch' 1976-1978: an overview of the trace metal, DDE, $\mathrm{PCB}$, hydrocarbon, and artificial radionuclide data. Environ. Sci. Technol. 17: 490-496

Flegal, A. R., Martin, J. H. (1977). Contamination of biological samples by ingested sediment. Mar Pollut. Bull. 8 (4) 90-92

Goldberg. E. D. (1975). Synthetic organohalides in the sea. Proc. R. Soc. Lond. (B) 189: 277-289

Goldberg, E. D. (1983). Removing a mood of uncertainty. Mar Pollut. Bull. 14 (5): 157

Goldberg, E. D., Bowen, V T., Farrington, J. W., Harvey, G., Martin, J. H., Parker, P. L., Risebrough, R. W., Robertson, W., Schneider, E., Gamble, E. (1978). The mussel watch. Environ. Conserv. 5: 101-125

Goldberg, E. D., Koide, M., Hodge, V., Flegal, A. R., Martin, J. (1983). U.S. mussel watch: 1977-1978 results on trace metals and radionuclides. Estuar. coast. Shelf Sci. 16: 69-93

Gordon, M., Knauer, G. A., Martin, J. H. (1980). Mytilus californianus as a bioindicator of trace metal pollution: variability and statistical considerations. Mar. Pollut. Bull. 11 (7): 195-198

Hoggins, F. E., Brooks, R. R. (1973). Natural dispersion of mercury from Puhipuhi, Northland, New Zealand. N. Z. Jl mar Freshwat. Res. 7: 125-132

Hungspreugs, M., Silpipat, S., Tonapong, C., Lee, R. F., Windom, H. L., Tenore, K. R. (1984). Heavy metals and polycyclic hydrocarbon compounds in benthic organisms of the Upper Gulf of Thailand. Mar. Pollut. Bull. 15 (6): $213-218$

Hungspreugs, M., Yuangthong, C. (1984). The present levels of heavy metals in some molluscs of the Upper Gulf of Thailand. Wat. Air Soil Pollut. 22: 395-402

Huschenbeth, E., Harms, U. (1975). On the accumulation of organochlorine pesticides, PCB and certain heavy metals in fish and shellfish from Thai coastal and inland waters. Arch. FischWiss. 26 (3): 109-122

IOC (1981). First Session of the WESTPAC Task Team on marine pollution research and monitoring using commercially exploited shellfish as determinants: summary report. IOC/WTTMPM-I/3, Intergovernmental Oceanographic Commission, Paris

Jensen, S., Renberg, L., Olsson, M. (1972). PCB contamination from boat bottom paint and levels of $\mathrm{PCB}$ in plankton outside a polluted area. Nature, Lond. 240: 358-360

Klumpp, D. W., Burdon-Jones, C. (1982). Investigations of the potential of bivalve molluscs as indicators of heavy metal levels in tropical marine waters. Aust. J. mar. Freshwat. Res. 33: 285-300

Latouche, Y. D., Mix, M. C. (1982). The effects of depuration, size and sex on trace metal levels in bay mussels. Mar. Pollut. Bull. 13 (1): 27-29

Lobel, P. B., Wright, D. A. (1982). Gonadal and nongonadal zinc concentrations in mussels. Mar. Pollut. Bull. 13 (9): 320-323

Lobel, P. B., Mogie, P., Wright, D. A., Wu, B. L. (1982). Metal accumulation in four molluscs. Mar Pollut. Bull. 13 (5): $170-174$

Menasveta, P., Cheevaparanapiwat, V (1981). Heavy metals, organochlorine pesticides and PCBs in green mussels, mullets and sediments of river mouths in Thailand. Mar. Pollut. Bull. 12 (1): 19-25 
NAS (1980). The international mussel watch. National Academy of Sciences, Washington D. C.

Nielsen, S. A. (1974). Vertical concentration gradients of heavy metals in cultured mussels. N. Z. Jl mar. Freshwat. Res. 8: 631-636

Nielsen, S. A., Nathan, A. (1975). Heavy metals in New Zealand molluscs. N. Z. Jl mar. Freshwat. Res. 9: 467-481

Orren, M. J., Eagle, G. A., Hennig, H. F.-K. O., Green, A. (1980). Variations in trace metal content of the mussel Choromytilus meridionalis (Kr.) with season and sex. Mar. Pollut. Bull. 11 (9): 253-257

Phillips, D. J. H. (1979). The rock oyster Saccostrea glomerata as an indicator of trace metals in Hong Kong. Mar. Biol. 53: $353-360$

Phillips, D. J. H. (1980a). Quantitative aquatic biological indicators: their use to monitor trace metal and organochlorine pollution. Applied Science Publishers Ltd., London

Phillips, D. J. H. (1980b). Proposal for monitoring studies on the contamination of the East Asian Seas by trace metals and organochlorines. Report UNEP/WG.41/INF.13, Food and Agriculture Organization, Rome, and United Nations Environment Programme, Geneva

Phillips, D. J. H., Muttarasin, K. (in press). Trace metals in bivalve molluscs from Thailand. Mar. environ. Res.

Phillips, D. J. H., Yim, W. W.-S. (1981). A comparative evaluation of oysters, mussels and sediments as indicators of trace metals in Hong Kong waters. Mar. Ecol. Prog. Ser. 6 : 285-293

Phillips, D. J. H., Thompson, G. B., Gabuji, K. M., Ho, C. T. (1982). Trace metals of toxicological significance to man in Hong Kong seafood. Environ. Pollut. Ser. B 3: 27-45

Siddall, S. E. (1980). A clarification of the genus Perna (Mytilidae). Bull. mar. Sci. 30 (4): 858-870

Sivalingam, P. M., Bhaskaran, B. (1980). Experimental insight of trace metal environmental pollution problems in mussel farming. Aquaculture 20: 291-303

Watling, H. R., Watling, R. J. (1976). Trace metals in Choromytilus meridionalis. Mar. Pollut. Bull. 7 (5): 91-94

Young, D. R., Heesen, T. C., McDermott, D. J. (1976). An offshore biomonitoring system for chlorinated hydrocarbons. Mar. Pollut. Bull. 7 (8): 156-159

This paper was presented by Dr. G. W. Bryan; it was accepted for printing on October 5, 1984 